\title{
Structural and thermal characteristic of IC engine piston using FEM approach
}

\author{
Manigandan. $\mathrm{A}^{1}$, Rajesh. $\mathrm{P}^{2}$, Stewak. $\mathrm{P}^{3}$, Surya. $\mathrm{S}^{4}$ and Nagaraj. $\mathrm{M}^{5}$
}

\author{
1, 2, 3, 4, 5 Mechanical Department, Loyola institute of technology, \\ Chennai-600123, Tamil nadu, India
}

\begin{abstract}
To investigate and analyses the thermal stress distribution of piston at the real engine condition during combustion process. This work advancement by utilizing finite element analysis to anticipate the higher stress and critical area are on the component. In order to find the displacement, thermal and stress appropriation of the piston, ANASYS software is utilized to analyse the piston under the thermal loads and mechanical loads. The outcomes are demonstrated that the temperature conveyance happens on the top point of the piston when the piston under the thermal load and the best stress happens on the piston stick when the piston under the heat structure coupling.
\end{abstract}

Keywords: combustion, I.C. engines, ignition, piston, static structural, steady state thermal.

\section{Introduction}

The name internal combustion alludes likewise to gas turbines with the exception of that the name is normally connected to responding interior ignition (I.C.) motors like the ones found in regular vehicles.

There are essentially two sorts of I.C. start motors, those which require a start plug, and those that depend on pressure of a liquid. Start motors take a blend of fuel and air, pack it, and touch off it utilizing a start plug.

Figure 1.1 demonstrates a cylinder and some of its essential parts. The name 'reciprocating' is given on account of the movement that the crank mechanism experiences. The cylinder chamber motor is fundamentally a wrench slider component, where the slider is the cylinder for this situation.

The cylinder is climbed and around the turning movement of the two arms or connections. The crankshaft turns which make the two connections pivot. The cylinder is typified inside an ignition chamber. The drag is the width of the chamber. The valves on top represent induction and exhaust valves necessary for the intake of an air fuel mixture and exhaust of chamber residuals.

In a spark ignition engine a spark plug is required to transfer an electrical discharge to ignite the mixture. In pressure start motors the blend touches off at high temperatures and weights.

The most reduced point where the cylinder comes to is called base perfectly focused. The most noteworthy point where the cylinder comes to is called top dead lope.

The proportion of base dead lope to top right on target is known as the pressure proportion. The compression ratio is very important in many aspects of both compression and spark ignition engines, by defining the efficiency of engines.

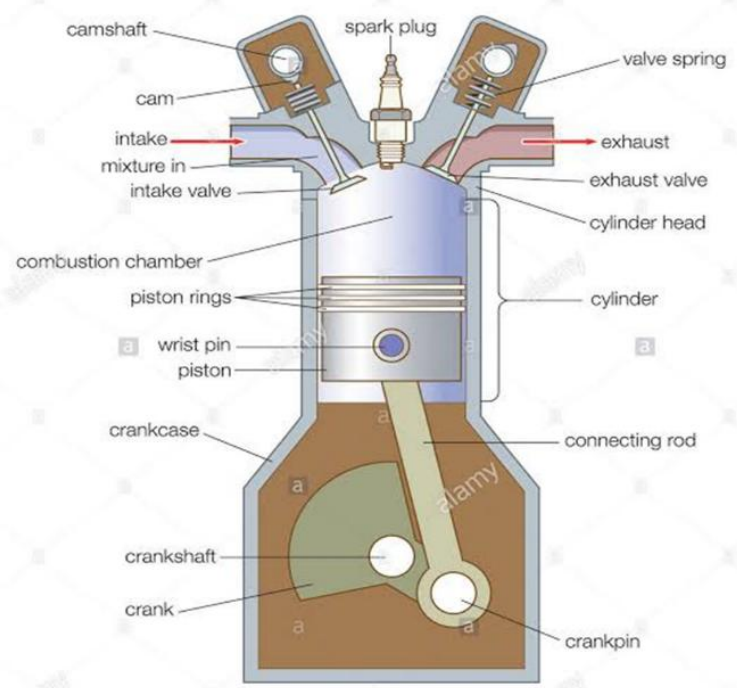

Fig 1 piston arrangement

\section{Review of Literature}

Design and Structural Analysis of Composite Piston survey: The cast iron pistons were superseded by aluminum alloy piston around the year 1920 (Sarkar 1975). Cole G.S. and Sherman A.M.(1995) explained that a considerable interest had been grown in replacing cast iron and steel in automotive component like piston with lightweight aluminum alloy casting to improve the performance and efficiency. Haque M.M and Young J.M. (2001) referred the low expansion group of aluminumsilicon alloy as piston alloy, since this group of alloy provides the best overall balance of properties. Near eutectic aluminum silicon piston alloy exhibit 
complex fatigue behavior due to their multi component microstructure12 Moffat et al 2005. Vaillant Phand Petitet J.P. 1995 studied on liquid aluminum which strongly reacts with iron, it forms brittle inter metallic compounds at the reinforcement region. Durrant G. et al (1996) explained about the aluminum alloy reinforced with mild steel insert by squeeze cast technique. The bonding of aluminum silicon alloy with the reinforced insert plays a vital role in improving the service life of the component. The importance on the suitable registry between these reinforced insert and alloy is restricted by the surface contaminants and surface oxides (Stefaniay et al 1987). The aluminium alloy casting having a porous metal insert improves the bonding strength by squeeze casing technique. The porous insert may be pre heated before the casting process in order to improve packing (Takatsuki 1990). The insert can also be coated by electro plating method which was explained by Han and More K.L. (2003). A stamped steel insert is used as an insert in metal die cast articles. The insert includes first and second interconnected stamped steel insert halves spaced from one another at certain locations to define a void. The edges of the insert lie below the surface of the casting to avoid bimetallic machining. However this is still in the early stages of development (Shimmell 1998). Dwivedi et al (2007) studied about reinforcement of the crown of a piston of aluminium or aluminium alloy for an internal combustion engine comprises the preparation of a reinforcement member which need not be exactly in the shape of disc, and it may be of any convenient shape (Graham 1986). Brittle intermetallic phases observed at interface reduce the life of component. Such problems can be alleviated by suitable techniques such as vibration assisted casting and heat treatment. Piston industries require such techniques.

\section{Material selection}

According to the requirement of the piston design, the material of piston should meet the following requirements:

1) High-intensity heat. When the temperature is 300 400 degree, it has also enough mechanical properties to prevent the parts damaged.

2) Good thermal conductivity and poor heat absorptive. Not only reduce the temperature of the top and ring, but also reduce the thermal stress.

3) The expansion coefficient is small. Keep the small gap with the piston and cylinder.
4) The specific gravity is small. Reduce the reciprocating inertia force of the piston group to reduce the mechanical load of the crankshaft and connecting rod.

\section{5) Good wear properties.}

6) Good manufacturability and cheap.

Based on the related researches, aluminum alloy is mostly used material in making car pistons, and experiments using other material such as cast iron, cast steel, ceramics and carbon. Here we consider a high-performance material, titanium alloy, which has very high tensile strength and toughness. It is light in weight, have extraordinary corrosion resistance and the ability to withstand extreme temperatures. Then analyses if it is feasible or not to expand the service life in the normal design way. The whole thickness of titanium alloy piston is large, but due to the small density of the titanium alloy, the mass is lighter than the cast iron piston, so it's good for the high speed engine.

At the same time, due to the high thermal conductivity of the titanium alloy, it make the water four stroke engines keep the good temperature when the engine injects the oil to cooling the temperature of inner wall. But the expansion coefficient of titanium is big, it is broken the gap of the cylinder and increase the friction loss. A piston ring material is chosen to meet the demands Set by the running conditions. Furthermore, the material should be resistant against damage even in emergency conditions. Elasticity and corrosion resistance of the ring material is required. The ring coating, if applied, needs to work well together with both the ring and the liner materials, as well as with the lubricant. Generally preferable materials are cast iron aluminum alloys grey cast iron Chromium coatings for rings Thin, hard coatings produced by PVD or CVD include coating compositions like titanium nitride ( $\mathrm{TiN})$, chromium nitride $(\mathrm{CrN})$; however coatings of this type are currently used exclusively for small series production for competition engines and selected production engines (Federal Mogul, 1998 Broszeit et al., 1999). Multilayer TiTiN coatings have been experimentally deposited onto cast-iron piston rings, and the coating is claimed to be more wear resistant than a chromium plated or phosphated surface, particularly when the number of layers is high (Zhuo et al., 2000) 
MATERIAL DATA

Silicon carbide reinforced Zirconium di boride Sic Reinforced ZrB2 > Constants

\begin{tabular}{|l|l|}
\hline Density & $\begin{array}{l}2.06 \mathrm{e}-006 \mathrm{~kg} \mathrm{~mm}^{\wedge}- \\
3\end{array}$ \\
\hline $\begin{array}{l}\text { Coefficient of Thermal } \\
\text { Expansion }\end{array}$ & $5.9 \mathrm{e}-006 \mathrm{C}^{\wedge}-1$ \\
\hline Thermal Conductivity & $9.37 \mathrm{e}-002 \mathrm{~W} \mathrm{mm^{ \wedge } -}$ \\
& $1 \mathrm{C}^{\wedge}-1$ \\
\hline Specific Heat & $5 . \mathrm{e}+005 \mathrm{~mJ} \mathrm{~kg} \mathrm{~kg}^{\wedge} 1$ \\
& $\mathrm{C}^{\wedge}-1$ \\
\hline
\end{tabular}

Sic Reinforced ZrB2 > Isotropic Secant Coefficient of Thermal Expansion

\begin{tabular}{|l|}
\hline Reference Temperature $\mathrm{C}$ \\
\hline 26.85 \\
\hline
\end{tabular}

\begin{tabular}{|l|l|l|l|l|}
\hline $\begin{array}{l}\text { Temperature } \\
\mathrm{C}\end{array}$ & $\begin{array}{l}\text { Young's } \\
\text { Modulus } \\
\mathrm{MPa}\end{array}$ & $\begin{array}{l}\text { Poisson's } \\
\text { Ratio }\end{array}$ & $\begin{array}{l}\text { Bulk } \\
\text { Modulus } \\
\mathrm{MPa}\end{array}$ & $\begin{array}{l}\text { Shear } \\
\text { Modulus } \\
\mathrm{MPa}\end{array}$ \\
\hline & $4.86 \mathrm{e}+005$ & 0.11 & $2.0769 \mathrm{e}+005$ & $2.1892 \mathrm{e}+005$ \\
\hline
\end{tabular}

Sic Reinforced ZrB2 > Isotropic Elasticity

Sic Reinforced ZrB2 > Tensile Yield Strength

\begin{tabular}{|l|}
\hline Tensile Yield Strength MPa \\
\hline 930 \\
\hline
\end{tabular}

Sic Reinforced ZrB2 > Tensile Ultimate Strength

\begin{tabular}{|l|}
\hline Tensile Ultimate Strength $\mathrm{MPa}$ \\
\hline 1070 \\
\hline
\end{tabular}

\section{Aluminum Silicon Carbide}

ALSIC > Constants

\begin{tabular}{|l|l|}
\hline Density & $2.937 \mathrm{e}-006 \mathrm{~kg} \mathrm{~mm}^{\wedge}-3$ \\
\hline Thermal Conductivity & $0.197 \mathrm{~W} \mathrm{~mm} \mathrm{~mm}^{\wedge}-1 \mathrm{C}^{\wedge}-1$ \\
\hline Specific Heat & $8.94 \mathrm{e}+005 \mathrm{~mJ} \mathrm{~kg}^{\wedge}-1 \mathrm{C}^{\wedge}-1$ \\
\hline
\end{tabular}

\section{ALSIC > Tensile Yield Strength}

Tensile Yield Strength MPa 450

ALSIC > Tensile Ultimate Strength

Tensile Yield Strength MPa 550
ALSIC > Isotropic Elasticity

\begin{tabular}{|l|l|l|l|l|}
\hline $\begin{array}{l}\text { Temperature } \\
\mathrm{C}\end{array}$ & $\begin{array}{l}\text { Young's } \\
\text { Modulus } \\
\mathrm{MPa}\end{array}$ & $\begin{array}{l}\text { Poisson's } \\
\text { Ratio }\end{array}$ & $\begin{array}{l}\text { Bulk } \\
\text { Modulus } \\
\mathrm{MPa}\end{array}$ & $\begin{array}{l}\text { Shear } \\
\text { Modulus } \\
\mathrm{MPa}\end{array}$ \\
\hline & $2.3 \mathrm{e}+005$ & 0.35 & $2.5556 \mathrm{e}+005$ & 85185 \\
\hline
\end{tabular}

\section{Aluminum Alloy}

Aluminium alloy $>$ Constants

\begin{tabular}{|l|l|}
\hline Density & $2.77 \mathrm{e}-006 \mathrm{~kg} \mathrm{~mm}^{\wedge}-3$ \\
\hline Coefficient of Thermal Expansion & $1 . \mathrm{e}-006 \mathrm{C}^{\wedge}-1$ \\
\hline Thermal Conductivity & $0.174 \mathrm{~W} \mathrm{~mm}^{\wedge}-1 \mathrm{C}^{\wedge}-1$ \\
\hline Specific Heat & $130 \mathrm{~mJ} \mathrm{~kg}^{\wedge}-1 \mathrm{C}^{\wedge}-1$ \\
\hline
\end{tabular}

Aluminium Alloy > Isotropic Elasticity

\begin{tabular}{|l|l|l|l|l|}
\hline $\begin{array}{l}\text { Temperature } \\
\mathrm{C}\end{array}$ & $\begin{array}{l}\text { Young's } \\
\text { Modulus } \\
\mathrm{MPa}\end{array}$ & $\begin{array}{l}\text { Poisson's } \\
\text { Ratio }\end{array}$ & $\begin{array}{l}\text { Bulk } \\
\text { Modulus } \\
\text { MPa }\end{array}$ & $\begin{array}{l}\text { Shear } \\
\text { Modulus } \\
\text { MPa }\end{array}$ \\
\hline & 71000 & 0.33 & 69608 & 26692 \\
\hline
\end{tabular}

Aluminium Alloy > Tensile Yield Strength

\begin{tabular}{|l|}
\hline Tensile Yield Strength $\mathrm{MPa}$ \\
\hline 280 \\
\hline
\end{tabular}

Aluminium Alloy > Tensile Ultimate Strength

\begin{tabular}{|l|}
\hline Tensile Ultimate Strength $\mathrm{MPa}$ \\
\hline 310 \\
\hline
\end{tabular}

Aluminium Alloy > Isotropic Secant Coefficient of Thermal Expansion

\begin{tabular}{|l|}
\hline Reference Temperature C \\
\hline 26.85 \\
\hline
\end{tabular}

\section{Results and analysis}

Aluminium alloy steady state thermal and static structural analysis

Geometry

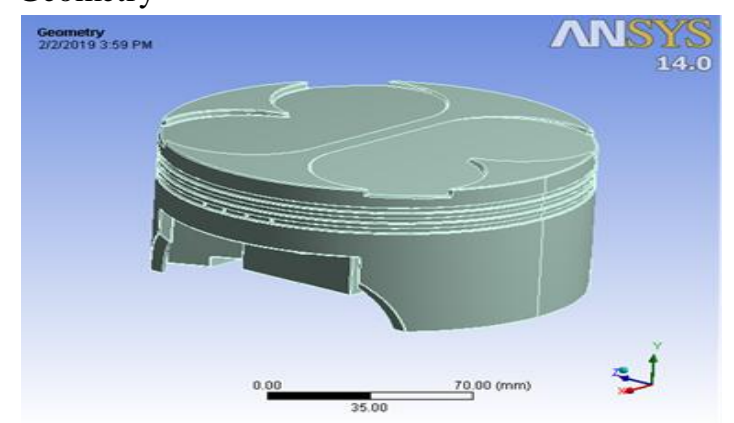


Mesh

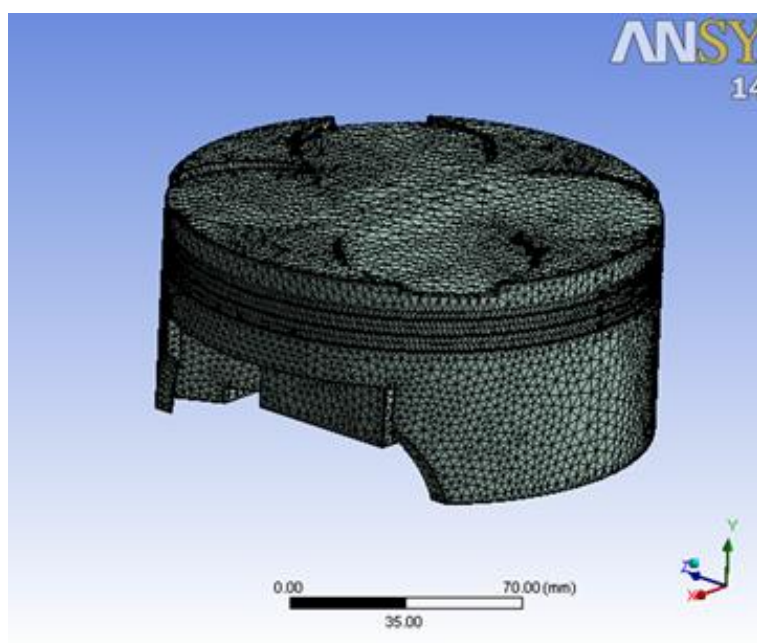

Aluminium alloy steady state thermal analysis

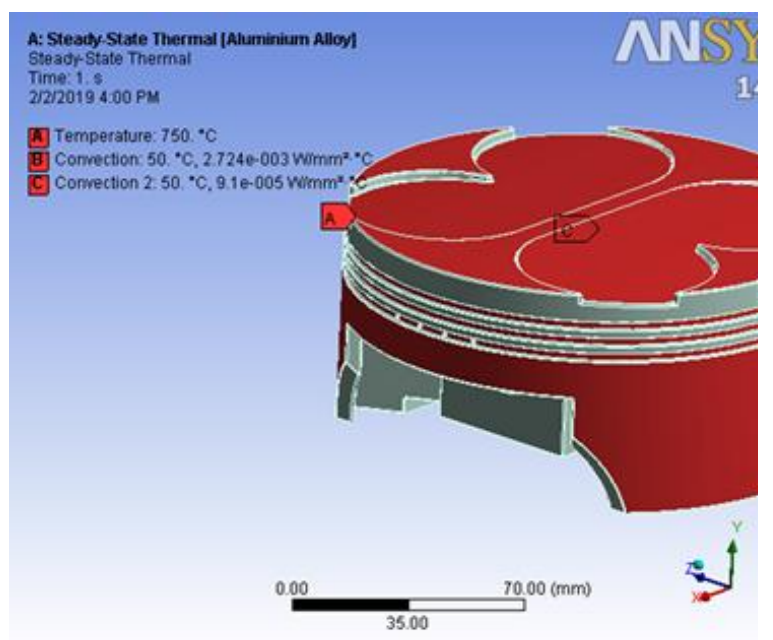

Temperature

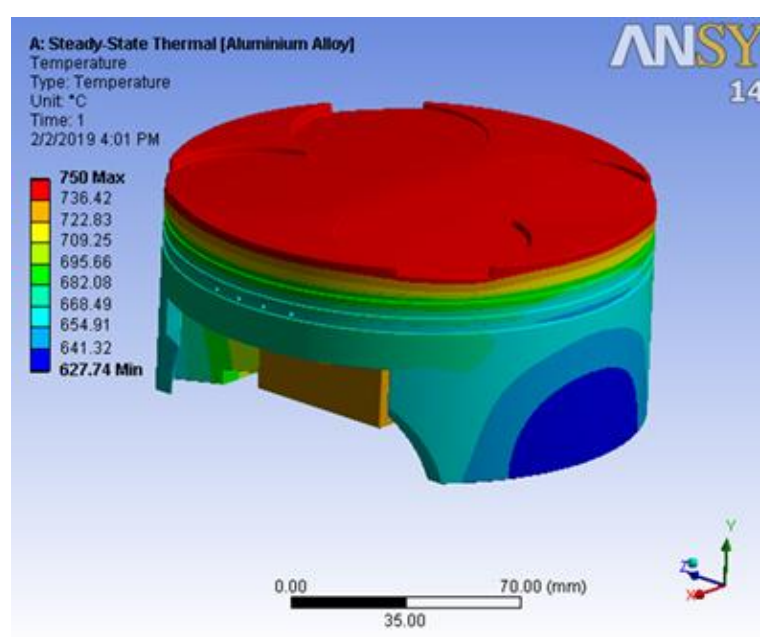

Total heat flux

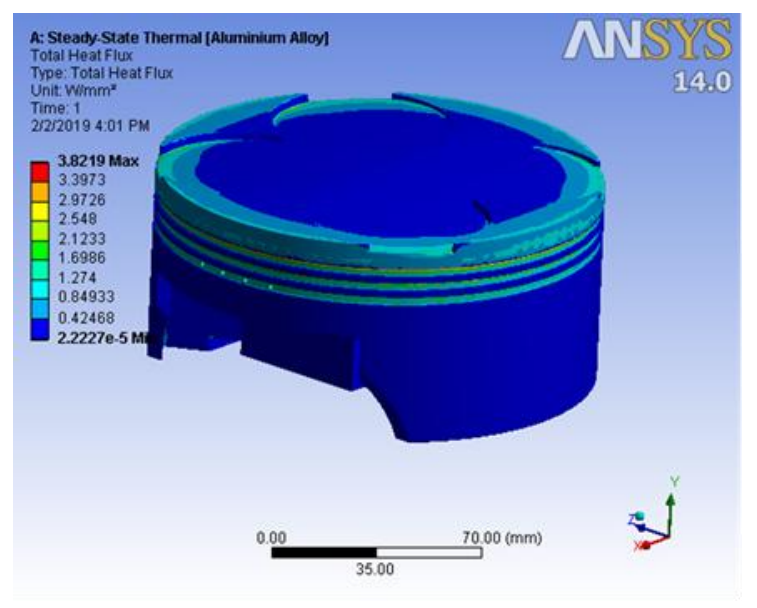

Static structural analysis

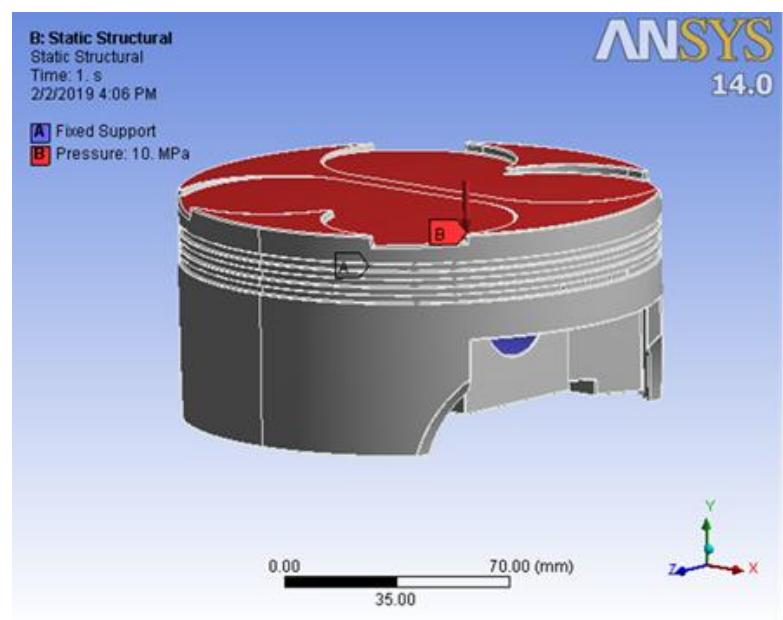

Total deformation

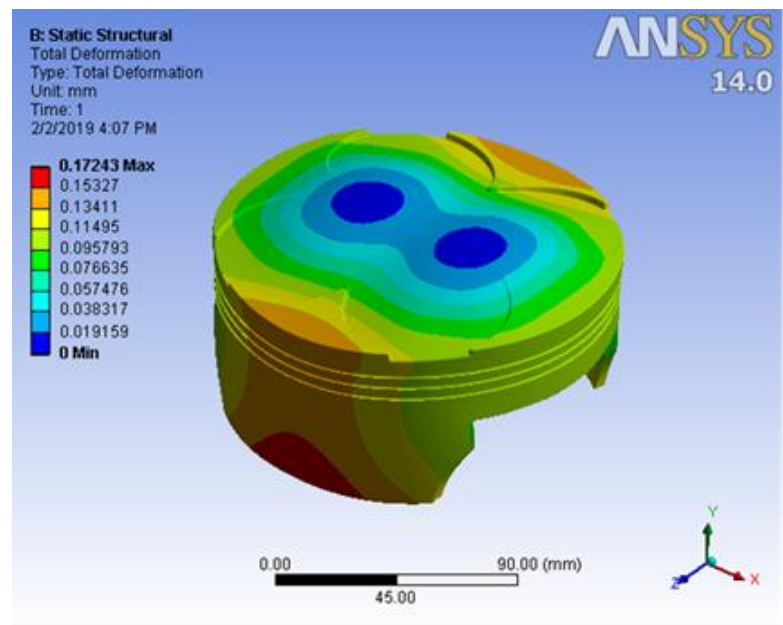


Equivalent Elastic Strain

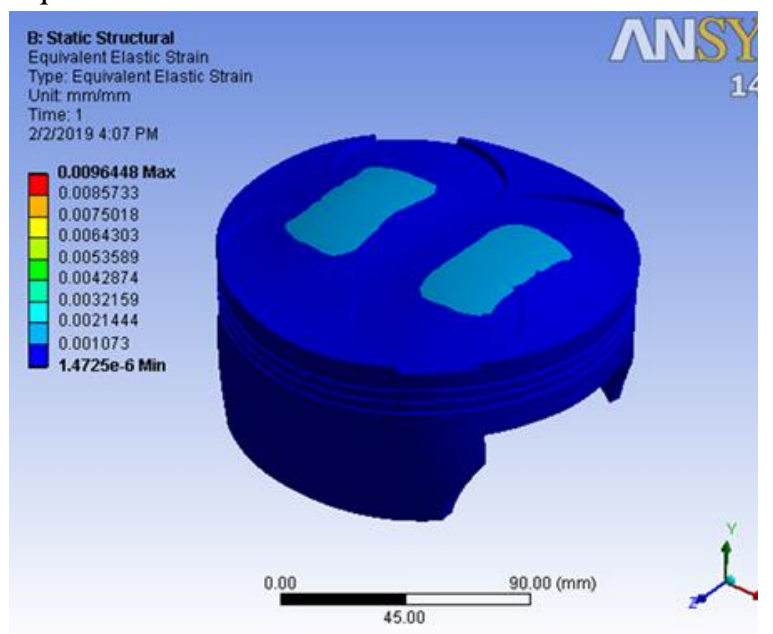

Equivalent Stress

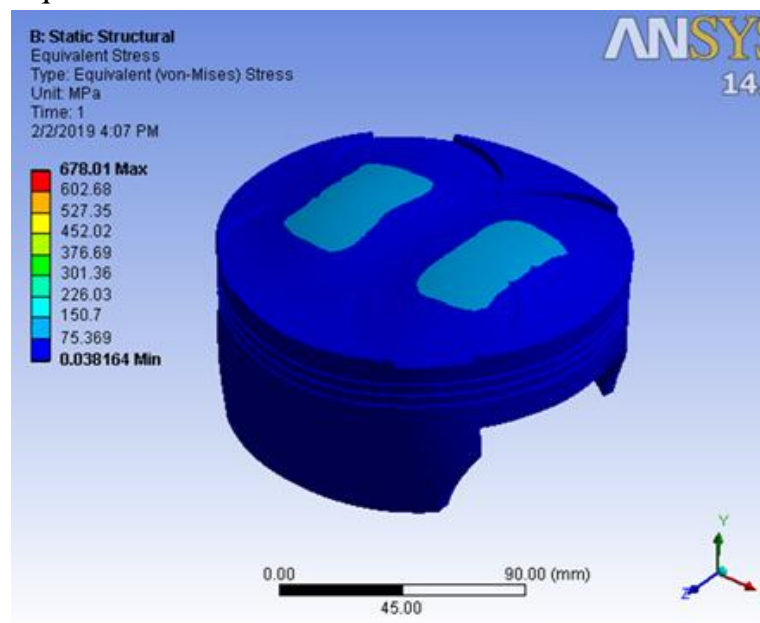

SIC reinforced $\mathrm{ZrB2}$ steady state thermal and static structural analysis

$\mathrm{SIC}$ reinforced $\mathrm{ZrB} 2$ steady state thermal analysis Temperature

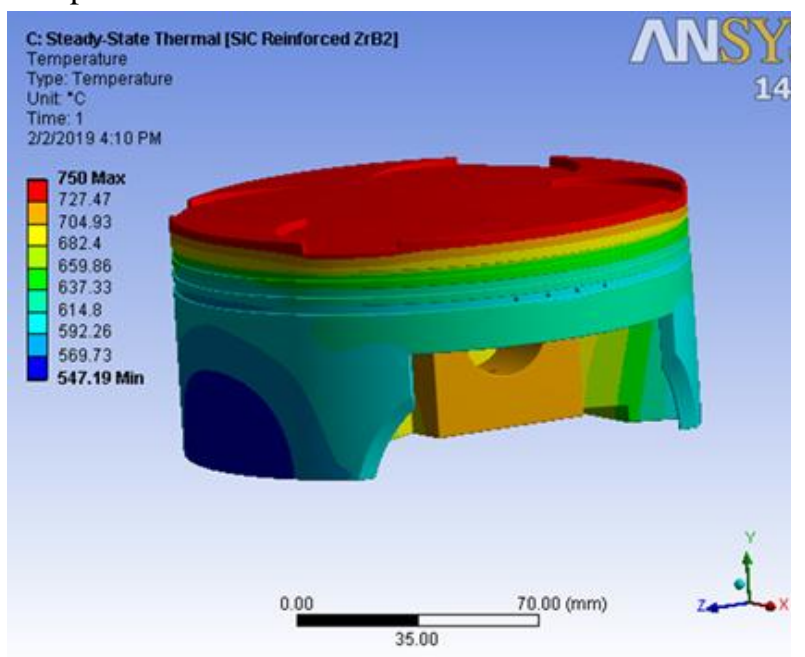

Total heat flux

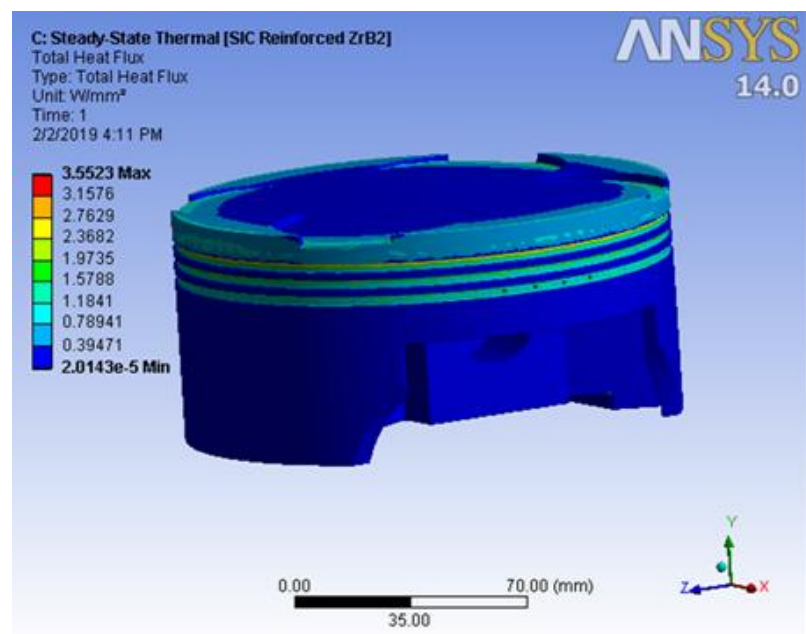

Steady state thermal

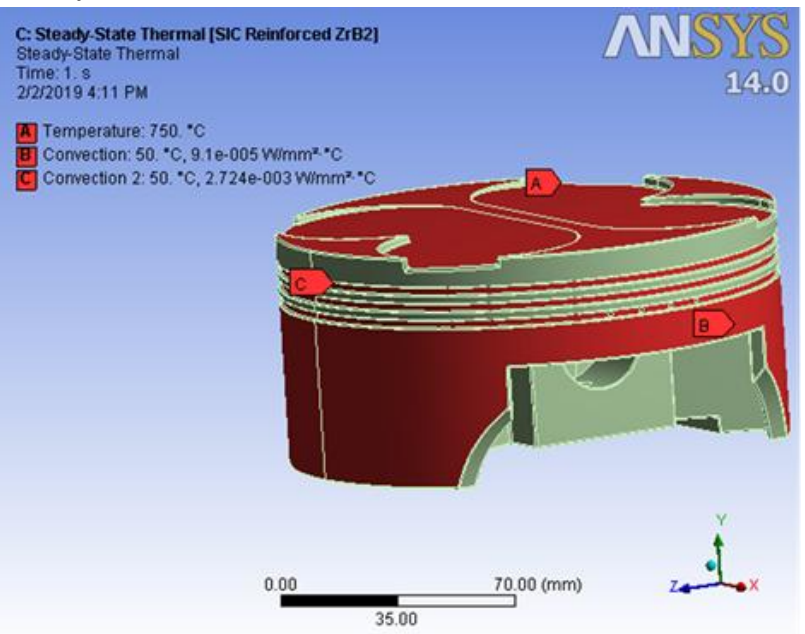

SIC reinforced ZrB2 static structural analysis

Total deformation

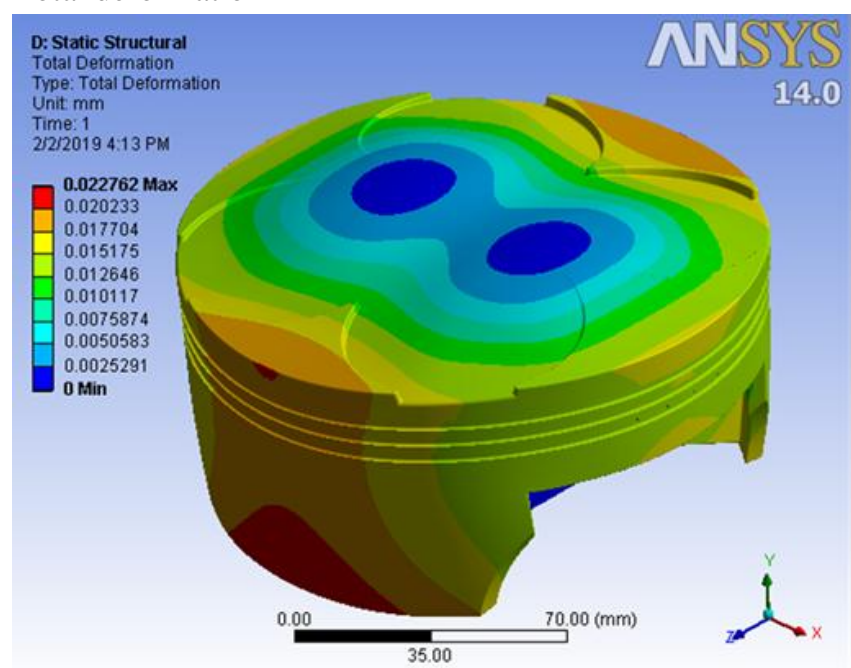


Equivalent elastic strain

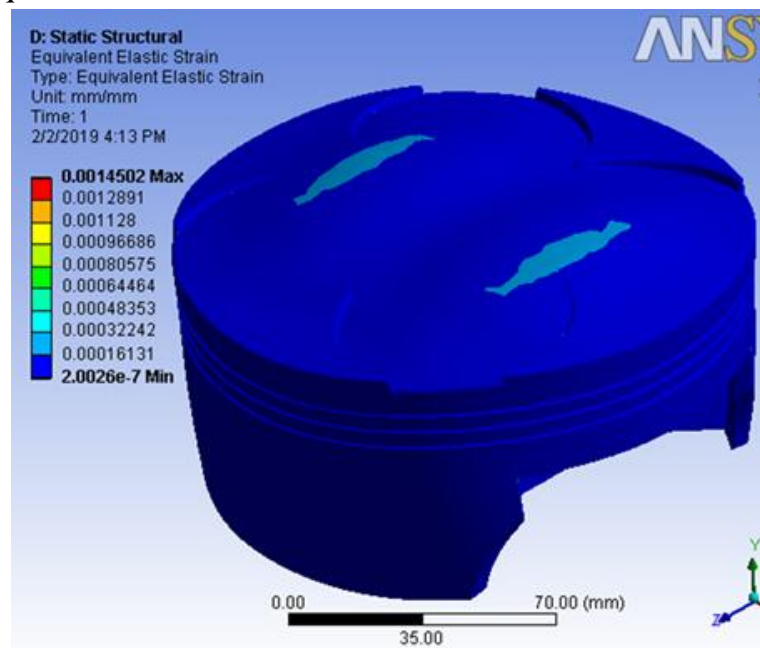

Equivalent stress

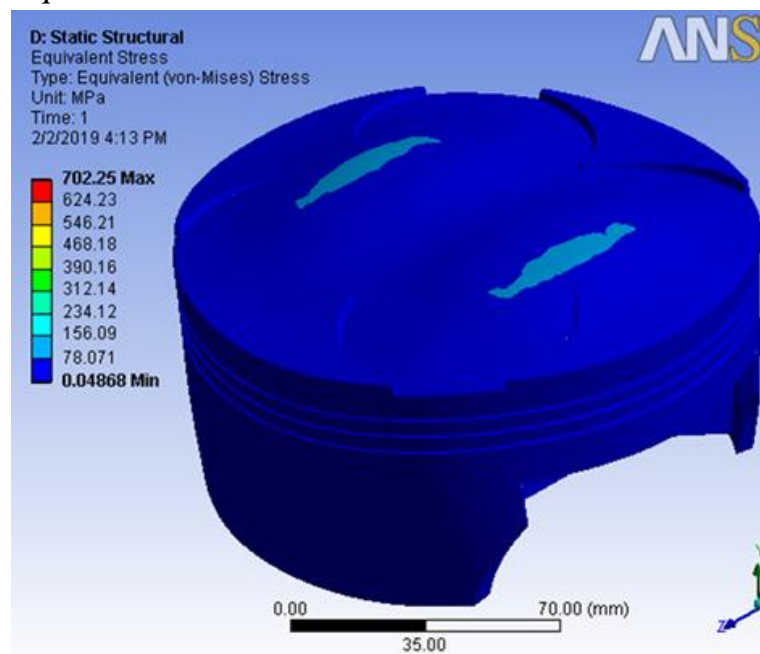

Aluminium Silicon Carbide steady state thermal and static structural analysis

Temperature

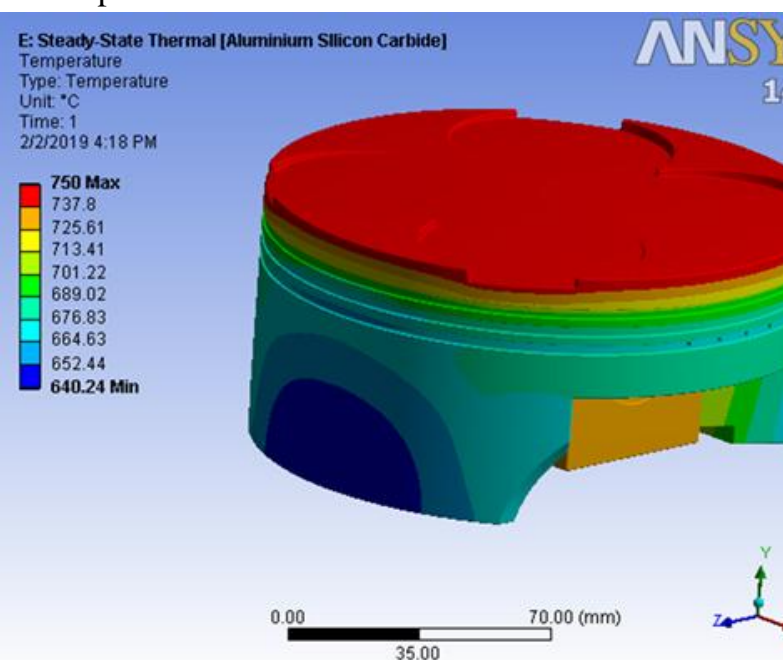

Equivalent elastic strain

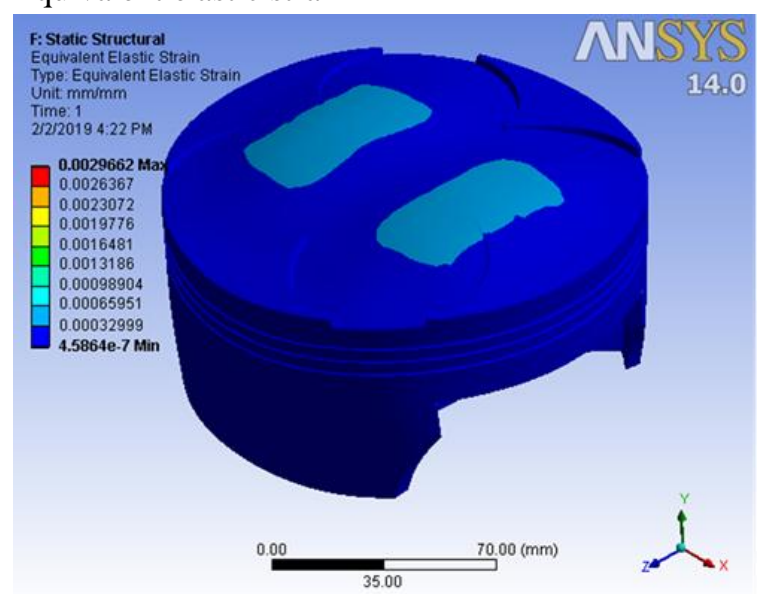

Total heat flux

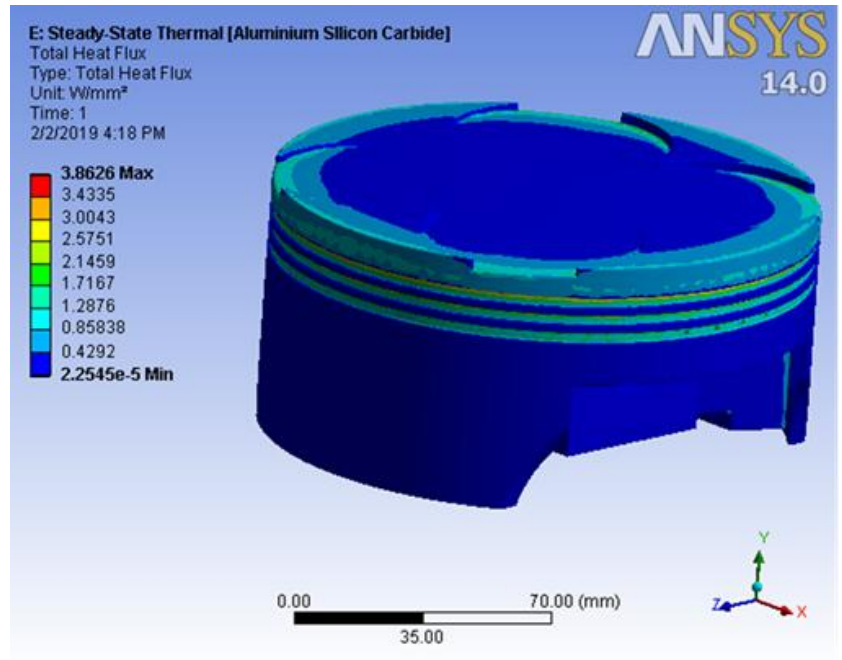

Aluminium Silicon Carbide static structural analysis

Total deformation

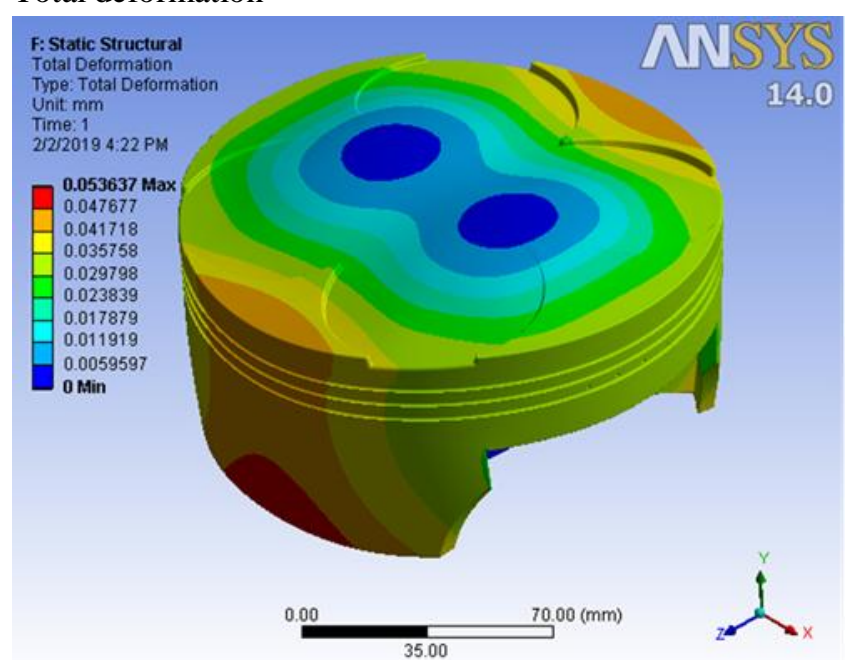


Equivalent stress

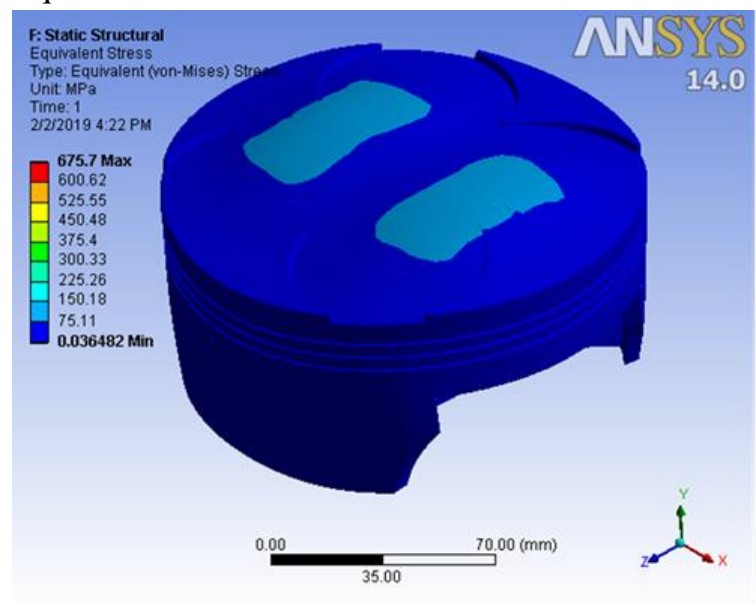

Result analysis of Piston

\begin{tabular}{|r|c|c|c|c|}
\hline $\begin{array}{c}\text { S. } \\
\mathbf{O}\end{array}$ & $\begin{array}{c}\text { Materials } \\
\text { /Results }\end{array}$ & $\begin{array}{c}\text { Aluminiu } \\
\mathbf{m} \text { Alloy }\end{array}$ & $\begin{array}{c}\text { Aluminium } \\
\text { Silicon } \\
\text { Carbide }\end{array}$ & $\begin{array}{c}\text { Silicon Carbide } \\
\text { Reinforce } \\
\text { Zirconium } \\
\text { diboride }\end{array}$ \\
\hline 1 & $\begin{array}{c}\text { Temperature } \\
{[\text { Degree Celsius] }}\end{array}$ & 627.74 & 640.24 & 547.19 \\
\hline 2 & $\begin{array}{c}\text { TotalHeat Flux } \\
{[\text { W/MM2] }}\end{array}$ & 3.8219 & 3.8626 & 3.5523 \\
\hline 4 & $\begin{array}{c}\text { Deformation } \\
{[\text { MM] }}\end{array}$ & 0.17243 & 0.053637 & 0.022762 \\
\hline 5 & $\begin{array}{c}\text { Equivalent Stress } \\
{[\mathrm{MPA}]}\end{array}$ & 678.01 & 675.7 & 702.25 \\
\hline & $\begin{array}{c}\text { Equivalent strain } \\
{[\mathrm{mm} / \mathrm{mm}]}\end{array}$ & 0.0096448 & 0.0029662 & 0.0014502 \\
\hline
\end{tabular}

\section{Conclusions}

The thermal, stress distribution of piston at the real engine condition during combustion process is analyzed.

Displacement, thermal and stress appropriation of the piston is found and the thermal loads and mechanical loads of the piston.

The outcomes are demonstrated that the temperature conveyance happens on the top point of the piston when the piston under the thermal load and the best stress happens on the piston stick when the piston under the heat structure coupling.

\section{Reference}

[1]G.S. Cole and A.M. Sherman, Lightweight materials for automotive applications, Mater. Char act. 35 (1995).

[2]Durrant. G. Gallerneault M. and Cantor B. (1996) 'Squeeze cast aluminum reinforced with Mild steel inserts' Journal of material science.

[3]Haque M.M. and Young J.M. (2001) 'Study on wear Properties of aluminum - 0315silicon piston Alloy' Journal of material processing technology.

[4]Vaillant Ph and Petitet J.P. (1995) 'Interaction under hydrostatic pressure of a mild steel with liquid aluminum alloy' Journal of material sciences.

[5].Moffat A.J. Barnes S. Mellor B.G. and Reed P.A.S. (2005) 'The effect of silicon content on long crack fatigue behavior on aluminum silicon piston alloys at elevated temperature' International journal of fatigue.

[6]Morishita (1981) 'Aluminum based alloy piston for internal combustion engines' U.S Patent.

[7]Sarkar A.D (1975) 'Wear of aluminum silicon alloy' Wear, Vol. 31.

[8]Stefaniay V. Griger A. and Turmezey T. (1987) 'Intermetallic phases in the aluminium-side corner of the AlFeSi-alloy system' Journal of Material science. 